\title{
QUALITY OF LIFE AT WORK OF CALL CENTER OPERATORS IN AN E-COMMERCE COMPANY IN SOUTHEAST BRAZIL
}

\author{
Lucas Alves de Oliveira Lima ${ }^{1} \boldsymbol{\Delta}$, Paulo Lourenço Domingues Junior ${ }^{1} \boldsymbol{凶}$, Ana Nele \\ Marci Rocha ${ }^{3}$, Debora Cristina Furtado Martins ${ }^{4}$, Maik Mateus de Souza 5 \\ ${ }^{1}$ Department of Administrative and Social Sciences/ITR, Federal Rural University of Rio de \\ Janeiro, Brazil \\ 2 Doctor in Sociology from the University of São Paulo and associate professor at the Federal Rural \\ University of Rio de Janeiro, Department of Administrative and Social Sciences/ITR, Brazil \\ 3,4,5 Department of Administrative and Social Sciences/ITR, Federal Rural University of Rio de \\ Janeiro, Brazil
}

DOI: https://doi.org/10.29121/granthaalayah.v8.i9.2020.1241

Article Type: Research Article

Article Citation: Lucas Alves de Oliveira Lima, Paulo Lourenço Domingues Junior, Ana Nele Marci Rocha, Debora Cristina Furtado Martins, and Maik Mateus de Souza. (2020). QUALITY OF LIFE AT WORK OF CALL CENTER OPERATORS IN AN E-COMMERCE COMPANY IN SOUTHEAST BRAZIL. International Journal of Research GRANTHAALAYAH, 8(9), 305-311. https://doi.org/10.29121/granthaa layah.v8.i9.2020.1241

Received Date: 15 September 2020 Accepted Date: 30 September 2020

\section{Keywords:}

Quality of Life at Work (QLW)

Job Satisfaction

Call Center

\section{ABSTRACT}

This research aimed to analyze the perception of Call Center operators of an E-Commerce company in the municipality of Três Rios/RJ about what is Quality of Life at Work (QLW), as well as what are the beneficial and harmful aspects of this kind of work. This is an exploratory qualitative approach research, where the case study technique was used with the application of structured interviews using a sample of ten workers. After collecting the data, it was possible to verify that the main perceptions about Quality of Life at Work (QLW) are linked to recognition and satisfaction in the work environment. In practice, beneficial factors such as constant learning, good interpersonal relationships and work infrastructure prevail. However, there is the prevalence of harmful aspects such as the high workload on Saturdays and the lack of better tools for carrying out activities. In addition, it was also found that two employees acquired stress, insomnia, eating disorders and anxiety due to customer complaints and high charges for goals.

\section{INTRODUCTION}

The Quality of Life at Work (QLW) has become nowadays a theme of study of several authors. For Scolari, Costa and Mazzilli (2009), this is due to the fact that the perception related to Taylor's ideas remains to this day in the workplace, where employees are often treated merely as productive resources. In this way, Taylorist methods have a direct impact on the physical and emotional health of the worker, since with the introduction of Scientific Administration, new physiological needs have arisen that were hitherto unknown and were imposed by the accelerated pace, times and goals.

(C) 2020 The Author(s). This is an open access article distributed under the terms of the Creative Commons Attribution License, which permits unrestricted use, distribution, and reproduction in any medium, provided the original author and source are credited. 
According to Parise and Soler (2016), one of the branches most affected by the high performance and goals is the Call Center, since this type of work encompasses activities between the organization and client in a virtual and/or telephone manner. Thus, the tasks contribute to impacting the quality of work life of people inserted in such a sector, because there are several ways to control the performance of employees for a better result. In addition, most customers make calls to make complaints, which enhances the possibility of the emergence of occupational diseases among the professionals who make the service.

Since 1990, the Call Center sector has been undergoing an expansion in Brazil with the privatizations of the telecommunications sector and triggering thousands of jobs for the population (OLIVEIRA, 2004). In equal proportion, the numbers of symptoms such as stress, anxiety, dissatisfaction and/or discomfort among Call Center operators due to the high demand for labor activities are growing (PARISE; SOLER, 2016).

From this perspective, Quality of Life at Work is a subject widely debated in the academic and business environments, since working conditions are currently aggravated by the constancy of profit maximization of companies. Thus, thinking about QLW has never been more important than in recent times, since it comes from a set of managerial actions with the purpose of promoting improvements in favor of workers' welfare (LIMONGI-FRANÇA, 1997).

Given this context, this research aimed to understand the perceptions about Quality of Life at Work (QLW) of Call Center operators of an E-Commerce company in the city of Três Rios (RJ). The study approached the understanding of QLW aspects revealing the harmful and beneficial factors of this kind of work.

\section{BIBLIOGRAPHICAL REVIEW}

In this section the theoretical framework will be presented, addressing the different concepts of Quality of Life at Work, which is the main theme of this research. In addition, this section will also seek to understand the evolution of the Call Center concept and its implications of the main theme within this structure.

\subsection{QUALITY OF LIFE AT WORK (QLW)}

According to Sant'Anna and Moraes (1998), the discussion on Quality of Life at Work (QLW) is not recent, it started after the Industrial Revolution, when working conditions started to be aggravated by the constant search around profit maximization, mainly after the emergence of Taylor's Theory of Scientific Administration. Still according to the authors, QLW gained notoriety from the Theory of Human Relations, which had as its purpose the humanization at work.

According to Chiavenato (2014), Quality of Life at Work constitutes the well-being of employees through adequate working conditions, thus involving psychological and physical elements of work.

From this perspective, Limongi-France (1997) seeks to consolidate the concept of Quality of Life at Work as the organizational actions that aim to promote the well being of employees, along with technological innovations that can help in the development of the organization. In this way, it encompasses a vision that seeks to meet the needs of workers in conciliation with organizational objectives.

Based on these aspects, QLW can be defined as a programme that aims to provide employees with job satisfaction through a favourable organisational climate. In this sense, the programs should involve physical, psychological and sociological factors taking into account technological changes (CONTE, 2003).

Quality of Life at Work is associated with combating taylorist methods and, although the term only appeared in 1950 in England, since ancient times there has been a search for improvements in work activities. Today, there are several approaches to QLW and, for Maximiano (2000, p. 498), "QLW is based on an integral view of people, which is the so-called biopsychosocial approach. The biopsychosocial approach of people originates from psychosomatic medicine, which proposes the integrated, or holistic, view of the human being".

In a broader perspective, Walton (1973) created a model that adopts eight criteria necessary for Quality of Life at Work, including aspects that go beyond the sphere of work. The author emphasizes that at work there should be the valorization of work skills with the possibility of career advancement and, thus, guarantee individual equality and equity between wages. In addition, a balance between professional and personal life is highlighted, as well as the adoption of an ethical posture by the company in relation to employees. 
Lucas Alves de Oliveira Lima, Paulo Lourenço Domingues Junior, Ana Nele Marci Rocha, Debora Cristina Furtado Martins, and Maik Mateus de Souza

\subsection{QUALITY OF LIFE AT WORK OF CALL CENTER OPERATORS}

According to Dantas (2008), the Call Center went through three stages, the first phase being based on a form of consumer communication with the organization, where the customer made complaints about the product or service through the SAC (Customer Service). In the second phase, the Call Center became a sector to build customer loyalty and, in this case, the organization made contact with consumers. In the third phase, the Customer Care Center was used as an essential tool to obtain organizational advantages, and the Call Center was recognized as a competitive differential tool among companies.

For Mancini (2006, p. 13) the most recent concept of the term Call Center is that of Contact Center, "which centralizes, regardless of the medium used (telephone, information technology, etc.), the management of all relations of the company with the society where it operates", and there is a direct relationship between all sectors of the organization.

Also according to Mancini (2006), the term Contact Center can be understood as the environment to which all the calls made by an organization's customers are directed, regardless of the media used. The term Call Center is popularly used for cases in which the service is made exclusively by telephone and, due to the existence of new technologies, it ended up being replaced by Contact Center, which considers other means of communication to make the contact between company and client.

According to Madruga (2009), the Call Center sector has become one of the sectors with the most standards and regulations in Brazil, because there are diseases that are common to Call Center operators, such as visual fatigue and organizational stress. Therefore, employees are more likely to develop occupational diseases because they are in constant care with consumers.

The technological advance has required electronic forms of service and, because of this, professionals in the Call Center sector are directly affected by high performance charges. Technology has caused significant changes in this type of work, intensifying the work and reducing the autonomy of workers. As a consequence, professionals have to perform more functions and develop monotonous activities capable of enhancing the emergence of stress (BALKA, 1995).

For Chiavenato (2014), stress is the reaction that arises from a restriction or need related to what a person wants in their environment. Stress in the work environment can come from factors such as the monotonous routine of some tasks, overload of functions, charges and authoritarianism on the part of superiors, factors that are increasingly present in the work of Call Center operators. These factors, according to the author, can be classified by two causes: environmental causes, which are linked to working environment conditions and include ringing of telephone sets, people talking, intense workflow; or personal causes, which are those not directly related to the organization and include individual characteristics such as lack of patience and personal problems that can predispose stress.

According to Chiavenato (2014), stress causes negative consequences that influence not only individuals but also the organization. These consequences can be individual, that is, those related to the health of the individual, such as depression, anxiety, among other diseases. However, these consequences can also affect the organization, decreasing productivity and increasing absenteeism rates, so the consequences of stress affect not only the employees, but also the organization as a whole.

Professionals in the Human Resources department, through research and observations, can contribute to ease the level of stress at work by identifying sources of stress in the organizational environment and proposing strategies based on new attitudes that make employees less impacted by sources of stress, or that these sources can be eliminated (CHIAVENATO, 2014).

\section{METHODOLOGY}

Regarding methodology, the exploratory research method of qualitative approach was used. According to Godoy (1995), for research to be considered qualitative, the phenomenon to be studied must be analyzed from an integrated perspective. It is necessary that data be collected and that they can be processed and analyzed in order to understand the phenomenon under study.

In this research, the case study method was used, which is a qualitative research method. According to Godoy (1995), the case study aims at a deep analysis of an environment, subject or situation. This qualitative research 
method is widely used by authors who seek to answer the questions "how" and "why" certain phenomena occur, being the observation and interview. the fundamental techniques used.

Thus, interviews were made with ten employees of the Call Center sector of an E-Commerce company located in Três Rios/RJ. In this case, a structured interview was used, which is characterized by having a questionnaire to support data collection (BONI; QUARESMA, 2005).

The interviews were prepared on the basis of a questionnaire composed of open-ended questions aimed at analysing experiences of "Quality of Life at Work". The questionnaire included questions about the profile of the respondents; what it is like to have a Quality of Life at Work; the positive and negative aspects in the company; whether they have had any illness from work; and finally, suggestions for improvement that would contribute to a quality of life at work.

According to Godoy (1995), the interview is often combined with observation. Thus, the data were transcribed by means of notes after the observations and, as the interviewee agreed, by means of recordings in order to obtain more precise data.

\subsection{COMPANY CHARACTERIZATION}

The company in which the research was carried out is from the Call Center sector and provides services in several branches of activities, such as import, industry and trade. The products made available by the company range from electro-electronics, which are the boss car, to household utensils, pet shop products, toys, textiles, leds and among others.

The main sales channel of the products are on the largest and most renowned E-commerce platforms in Brazil, which generates in normal day of sales, an average of 1800 orders billed that tends to provide a large volume of phone calls, online chats and emails referring to pre-sales and post-sales, this work performed by Call Center operators.

The call center sector is a structure that aims to serve customers with the use of a computer terminal and a telephone set. Thus, the company contains rooms conjugated by sectors and has an infrastructure separated by bays equipped with computers and telephone terminals.

The organization also has a security regiment with 24 hour monitoring through cameras in all environments, except the private ones, besides metal detectors in the accesses to the sectors. It should be noted that the employee is offered transportation by an outsourced company that operates at all times ensuring the departure and return of employees.

The company is located in the interior of Rio de Janeiro in the city of Três Rios, $125 \mathrm{~km}$ north of the state capital. The city is part of the industrial axis of the cities near BR 040 and BR 393 and has an area of $322,843 \mathrm{~km}^{2}$, being located in the South-Fluminense region in Southeast Brazil (IBGE, 2018).

\section{RESULTS AND DISCUSSION OF THE DATA}

Through the survey conducted with ten employees of the Call Center sector in the E-Commerce company located in the municipality of Três Rios/RJ, it was possible to find that of the workers interviewed seven are women and three are men, i.e., a female preponderance in the sector is perceived. This fact evidenced in this research is not an isolated case of the company under study, since authors such as Ziliotto and Oliveira (2014) point out that women are predominant in the Call Center sector.

In addition, when asked about their position, it was found that nine are Call Center operators in customer service, while one is supervising the auxiliaries. It is worth noting that all have a workload of forty-four hours per week, this being the maximum load provided for in Article 7 of the 1988 Constitution of the Federative Republic of Brazil.

As for age, the age groups varied from 21 to 47, with only two people under 24, which shows that there are few young people in the area. According to the sector supervisor, now called E8, the number of young people is due to the fact that

Young people are not very tolerant of the kind of work this sector requires, because I realize that they do not have much patience due to repetitive functions. The work consists of phone answering in great potential, that is, it has a lot of phone calls. This requires the operator to be focused all the time on the computer screen, performing 
Lucas Alves de Oliveira Lima, Paulo Lourenço Domingues Junior, Ana Nele Marci Rocha, Debora Cristina Furtado Martins, and Maik Mateus de Souza

repetitive functions, making this work extremely stressful. In this case, the call is usually from a complaining and/or cursing customer, a factor that ends up generating greater wear and tear among young people who do not know how to handle it very well (E8).

The professionals hired have the basic education required by the company to have completed high school and they seek knowledge and improvement, showing that they want growth in the company. After all, three of them are in higher education; one has incomplete higher education; and the rest have completed high school.

When asked about the length of professional experience, it was evident that the length of experience in the labour market for interviewees ranges from six months to twenty-five years. In relation to the time spent in the position in the company, the three who have just gone through the period of experience (of ninety days) have been working for three months. The others are between eight months and four years.

In addition, five employees are married and five are single. Of these ten, eight have a child; one is pregnant with her first child at thirty at eight weeks of gestation; and only one interviewee has no children.

After understanding the respondents' profile, questions were asked regarding the central theme of this survey, which is Quality of Life at Work (QLW). Thus, when asked what it is to have Quality of Life at Work (QLW), the workers answered the following: five said aspects about what it is to have recognition at work, either by valuing work or material gain; two said it is to have satisfaction at work; one said it is to have a decent salary without exploitation; one said it is to have a good relationship with co-workers, as well as an adequate place to work; and one said it is to be able to reconcile personal and professional life.

In view of this, it can be seen that most workers believe that Quality of Life at Work (QLW) is associated with recognition and satisfaction at work, a view on the concept of the similar theme with that of Chiavenato (2014), which associates Quality of Life at Work with recognition of employees, along with the physical conditions of the work environment worthy of performing the tasks, thus providing the well being and satisfaction of workers, then achieving Quality of Life at Work.

In the second question regarding Quality of Life at Work (QLW), there was the inquiry about the positive factors of the work environment, among which could be summarized in three answers: constant learning, the relationship with co-workers and good work infrastructure, as can be seen in the reports of respondents E2 and E9.

Without a doubt, the main positive factor is the infrastructure of the site. I have all the comfort of the environment necessary to perform my task. I've worked in some companies and I've never had as much comfort as I do now. I spend all day sitting in the sector and this does not affect me, because the company offers great working conditions. I am also always in constant learning, which makes me have satisfaction as a professional (E2).

I have a great team and this contributes to my quality of life at work. Being in an environment where you know that people like you is something that brings a certain comfort. The harmonic relationship ends up making the work here less stressful and, consequently, better (E9).

It is noted that the organization seeks to offer a physical working environment that is considered worthy by its employees, since the infrastructure has an important role for the performance of employees, because people spend much of their time at work and will act more effectively with a suitable place to perform the tasks.

In this perspective, it was possible to find out that there is air conditioning in the work environment, chairs with pillows, women's and men's restrooms as well as a cup for quick meals. The shared area has a cafeteria with television, air conditioning, refrigerator, oven, microwave and electric oven. The company also provides American cutlery and games at the tables. The cloakrooms have individual lockers with locks, washbasins, mirrors, toilets, showers and reserved for handicapped people and support seats.

Furthermore, it is possible to observe that there is a good interpersonal relationship at work, which contributes to strengthen team spirit and, consequently, make mutual help between employees. Such aspects will contribute to an engagement among the professionals and a favorable organizational climate, thus making it conducive to the consolidation of a synergistic effect where everyone compresses the same feelings in favor of a single goal.

However, when asked about the negative factors of work that hinder Quality of Life at Work (QLW), it was possible to verify that they are factors originating from environmental causes, since four of the interviewees reported to be the high workload on Saturday; two reported to be the lack of better tools for carrying out the work; one reported to be the complaints from clients; and one reported to be the high collection by targets. It is important to note that only one person reported having no negative factors. Thus, it is noticeable that although there is an adequate infrastructure in the work environment, all the problems considered harmful by the respondents come 
from the organization itself, which shows that there are no factors related to personal causes that compromise the quality of life at work.

Employees were asked if they had any work-related health problems. Eight said no, while two said yes, being supervisor E8 and an attendant named E3. Supervisor E8 reported the following: "Due to the high level of billing, goals and leadership over attendants, I ended up getting high blood pressure, stress, eating disorders and insomnia." The interviewee E3, who acts as a customer service operator, informed me that "because of the work, I suffer with anxiety. With a lot of cost I managed to overcome alcoholism and smoking. Sometimes, the customers are incomprehensible or coarse, which ends up contributing for me to take stress into the home."

This will therefore contribute to affecting the well-being of workers and may therefore have an impact on the productivity of the organisation. Nowadays the competitive differential of companies is in people, and if the professionals do not have a well being at work, they will not work effectively, which will directly affect the organizational results. The results obtained corroborate the theory, since Madruga (2009) highlights that Call Center workers are susceptible to illness at work, a fact that was observed between two individuals in this research.

Depending on the above, the professionals pointed out suggestions for improvements related to the main difficulties faced by the organization, where three reported that an area is needed to rest at lunchtime; two reinforced the issue of improving the workload on Saturday; two suggested more benefits; one emphasized more training; one highlighted better tools for the work; and one emphasized greater recognition of the work done by employees. Therefore, it is clear from the previous information that there is a concern of professionals around leisure, either at work through a greater rest in lunch hours, or out of work through a lower workload on Saturday for a longer leisure time at the weekend.

\section{CONCLUSION}

The research aimed to analyze which concepts the operators of a Call Center company have on the subject of Quality of Life at Work and whether these concepts are experienced within the organization as beneficial factors. In addition, the research also sought to observe whether there are harmful experiences that may interfere with Quality of Life at Work.

Thus, it was found that most workers associate the issue with recognition for the activities performed and, secondly, with job satisfaction. In practice, beneficial aspects such as good site infrastructure, good relations with colleagues and constant learning prevail. It is concluded that the company seeks to provide decent working conditions in the infrastructure so that employees are satisfied with the working environment. However, aspects such as high workload on Saturday days and the lack of better tools to perform the activities compromise the quality of life in the company.

In addition, it was found that there are experiences of stress among some employees within the organization, since the company has a high level of charging per target beat and, moreover, employees are in direct contact with several customers during the work period, which leads to a high level of stress at the end of the day. According to reports from the employees themselves, these daily experiences of stress end up causing some of these individuals to acquire problems such as anxiety, high blood pressure and eating disorders.

Therefore, it is proposed that the organization effectively seeks the satisfaction and well-being of employees, always seeking to reduce the relevant factors that may cause stress. It is important that employees are satisfied with the working environment as a whole, so that they perform their respective tasks motivated, and thus the organization has satisfied employees and customers.

\section{SOURCES OF FUNDING}

This research received no specific grant from any funding agency in the public, commercial, or not-for-profit sectors.

\section{CONFLICT OF INTEREST}

The author have declared that no competing interests exist. 
Lucas Alves de Oliveira Lima, Paulo Lourenço Domingues Junior, Ana Nele Marci Rocha, Debora Cristina Furtado Martins, and Maik Mateus de Souza

\section{ACKNOWLEDGMENT}

None.

\section{REFERENCES}

[1] BALKA, E. Technology as a factor in women's occupational stress: the case of telephone operators. In: Messing K, Neis B, Dormais. Invisible, La santé des travailleuses. Canadá: Gynergy Books, 1995.

[2] BRASIL. Constituição (1988). Constituição da República Federativa do Brasil. Brasília, DF: Senado Federal: Centro Gráfico, 1988.

[3] BONI, V.; QUARESMA, J. L. Aprendendo a Entrevistar: como fazer entrevistas em Ciências Sociais. Florianópolis: Revista Em Tese, v. 2, n. 1, p. 68-80, 2005

[4] CHIAVEnATO, I. Gestão de Pessoas. 0 novo papel dos recursos humanos nas organizações. 4. Ed. São Paulo: Manole, 2014.

[5] CONTE, A. L. Qualidade de vida no trabalho. Curitiba: Revista FAE BUSINESS, n. 7, nov., p. 32-32, 2003.

[6] DANTAS, E. B. Telemarketing: a chamada para o futuro. 5a Ed. São Paulo: Atlas, 2008.

[7] GODOY, A. S. Pesquisa qualitativa: Tipos Fundamentais. Revista de Administração de Empresas, v. 35, n. 3, p. 21, 1995.

[8] IBGE. População no último censo. Disponível em: <https://cidades.ibge.gov.br/brasil/rj/tresrios/panorama>. Acesso em 5 out, 2019.

[9] LIMONGI-FRANÇA, A C. L. Qualidade de Vida no Trabalho: conceitos, abordagens, inovações e desafios nas empresas brasileiras. Rio de Janeiro: Revista Brasileira de Medicina Psicossomática, 1997.

[10] MADRUGA, R. Call Centers de Alta Performance: manual indispensável para todos que buscam a excelência no atendimento. São Paulo: Atlas, 2009.

[11] MANCINI, L. Call Center: estratégia para vencer. São Paulo: Sumus, 2006.

[12] MAXIMIANO, A. C. A. Teoria geral da administração: da escola cientifica à competitividade na economia globalizada. 2a ed. São Paulo: Atlas, 2000.

[13] OLIVEIRA, S. M. Reestruturação das Telecomunicações no Brasil: uma (re)visão das estratégias de gestão da produção e das relações de trabalho na cadeia produtiva. Estudo de caso da telefonia fixa em São Paulo - 19902003. 2004. Tese (Doutorado em sociologia). São Paulo, FFLCH/USP, 2004.

[14] PARISE, J. A.; SOLER Z. A. S. G. Quality of working life of call - center workers. Revista Brasileira de Enfermagem, v. 69, n. 4, p. 704 -709. 2016.

[15] SANT'ANNA, A. S.; MORAES, L. F. R. O movimento da qualidade de vida no trabalho: um estudo de suas origens, evolução, principais abordagens e avanços no Brasil. Belo Horizonte: CEPEAD - UFMG, 1998.

[16] SCOLARI, C.; COSTA, S.; MAZZILLI, C. Prazer e sofrimento entre os trabalhadores de Call Center. São Paulo: Revista de Psicologia - USP, vol.20 n.4, 2009.

[17] WALTON, R. E. Quality of working of life: What is it?. Cambridge: Slow Management Review, v. 15, n. 1, p. 1121, 1973.

[18] ZILIOTTO, D. M.; OLIVEIRA, B. O. A organização do trabalho em call centers: implicações na saúde mental dos operadores. Revista Psicologia: Organizações e Trabalho, v. 14, n. 2, p. 169 - 179, 2014. 